\title{
Inventory of Instruments of Critical Thinking
}

\author{
John Follman, Carolyn \\ LAVELy \& NeAL BERger
}

University of South Florida

Since about 1983 the venerable construct of critical thinking has become an educational juggernaut. See Follman (1987) for an overview of this recent critical thinking activity, and also Follman (1991) for a correlative overview of the recent critical reading activity.

A main plank in the rationale for enhancing critical thinking of children in general is the finding that $80 \%$ of third graders, more than half of seventh graders, and $36 \%$ of eleventh graders scored minimally or inadequately when reading critically (Vobejda). More specifically, of 36,000 public and private school students, less than $1 \%$ of third graders, $8 \%$ of seventh graders, and $23 \%$ of eleventh graders performed at the highest level on reading performance on the National Assessment of Educational Progress.

The purpose of this note is to inventory the contemporary critical thinking instruments. These instruments are identified for possible use in psychometric investigations of the nature and definition of the construct of critical thinking and especially for use as dependent variables in studies to determine the efficacy of independent variables purported to enhance people's critical thinking.

For compilations of early critical thinking tests see An experiment in the development of critical thinking (Glaser, 1941), Education for effective thinking (Burton, Kimball \& Wing, 1960), and a list of 30 instruments (Ness, 1967).

More recent compilations of critical thinking tests have been reported by Stewart (1979), Baker (1981), Ennis (1986), Follman (1987), Norris \& Ennis (1989), Facione (1989; 1990, 1992), Facione \& Facione (1992), among others.

Baker (1981) compiled the contemporary critical thinking tests and identified 26, six described as then currently available and 20 as published but not readily available. The six currently available tests were: Watson-Glaser Critical Thinking Appraisal; Cornell Critical Thinking Test Level Z; Test of Thematic Analysis; Analysis of Arguments; College Outcomes Measures Project; and

(C) Informal Logic Vol. 18, Nos. 2 \& 3 (1997): pp. 261-267. 
COMP-Objective Test (CACTP). The 20 not readily available tests were: $C r e a-$ tive Writing on a Social Problem; Charley Brown test with no name; $A$ Test of Critical Thinking in the Social Sciences; A Test of Critical Thinking, Form G; Inventory of Social Understanding I; Charles Logan unnamed test; Testing of Study Skills and Critical Thinking Section II; Testing of Study Skills and Critical Thinking Section V; Test of Study Skills and Critical Thinking VI; Testing of Study Skills and Critical Thinking Section XIII; Testing of Study Skills and Critical Thinking Section XV; Testing of Study Skills and Critical Thinking Section XVI; Testing of Study Skills and Critical Thinking XVII; Social Issues Analysis Test 1; Social Issues Analysis Test 2; Social Issues Analysis Test 3; Social Issues Analysis Test 4; David Simon unnamed test; and Interpretation of Data Test.

Follman (1987) overviewed the contemporary critical thinking tests, and, in addition to the tests above, identified: The Curry Test of Critical Thinking (Landis \& Michael, 1981); The New Jersey Test of Reasoning; The Whimbey Analytical Skills Inventory (Whimbey, 1985, October); a history-social studies with critical thinking skills test (Kneedler, 1986); the Group Assessment of Logical Thinking (Yeany, Yap \& Padilla, 1986); The Ennis-Weir Critical Thinking Essay Test (Ennis, 1986); and state developed tests including one to be administered to fourth graders in Michigan (Ranbom, 1985, March 6), one in New Jersey (Whimbey, 1985, October), and one in Connecticut (Sternberg \& Baron, 1985).

Baron (1987) compiled six multiple choice and one essay "tests that could be called critical thinking tests, at least in part." Tests not previously mentioned above include Basic Skills for Critical Thinking; Cornell Critical Thinking Test, Level X; and Ross Test of Higher Cognitive Processes.

A contemporary overlapping inventory of instruments was prepared by Kennedy, Fisher \& Ennis (1987). They classified the tests into two types, multiaspect, and aspect-specific. The multi-aspect tests were: Cornell Critical Thinking Test Level X; Cornell Critical Thinking Test Level Z; New Jersey Test of Reasoning Skills; Ross Test of Higher Cognitive Processes; Watson-Glaser Critical Thinking Appraisal; and Ennis-Weir Critical Thinking Essay Test. The aspect-specific tests were: Cornell Class-Reasoning Test, Form X; Cornell Conditional-Reasoning Test, Form X; Logical Reasoning; and Test of Enquiry Skills (Australia). Kennedy et al. considered their list comprehensive. Another more recent Ennis iteration was by Norris \& Ennis (1989) which included Judgment: Deductive Logic and Assumption Recognition and Test on Appraising Observations as well as those above.

One of several more recent critical thinking instruments, The Test on Appraising Observations, measures the ability to evaluate statements of observations, was constructed by Norris (1988). The National Center for Research to Improve Postsecondary Teaching and Learning (NCRIPTAL) (1989) identified the Chickering Critical Thinking Behoviors Inventory in which students report 
the percent of time spent on memorizing, interpreting, analyzing, synthesizing, and evaluating. NCRIPTAL also identified several open-end measures of thinking: The Measure of Intellectual Development, a subjective measure of decision making, careers, and classroom learning; The Analysis of Argument; The American College Testing Program's College Outcome Measures Program, a test of reasoning; and more importantly the Reflective Judgment Interview ( $R J I)$, in which an interviewer asks a student questions about an ethical dilemma presented orally and in writing. The $R J I$ is currently receiving considerable research attention. Another less formal system was developed by the Maryland Center for Thinking Studies (METS) for younger pupils. METS uses taped interviews primarily. Also used are performance assessment matrices, debriefing wheels, think logs, student journals, parent and studentquestionnaires, classroom observations, teacher diaries, and structured faculty debriefing sessions (Worsham, 1991).

Facione (1990) assembled a panel of critical thinking experts to identify critical thinking skills and sub-skills. The panel also identified a number of additional contemporary critical thinking tests including: the Test on Appraising Observations 1983; The American College Testing Program 1988 Collegiate Assessment of Academic Proficiency which included a critical thinking measure; the Valett Inventory of CT Abilities; Test of Cognitive Skills 1981, McGraw Hill; subscores on inference and evaluation and logical evaluation in the Basic Skills Assessment 1977-81 McGraw Hill; Test of Problem Solving 1984 Lingui System; Corrective Reading Mastery Test 1980, SRA; Ball Aptitude Battery. Facione also included a useful bibliography of critical thinking assessment references.

The Wisconsin Research and Development Center for Cognitive Learning has compiled an inventory of 37 measures of cognitive abilities at the intermediate grade level.

In order for the reader to have an appreciation of the scientific significance of tests of critical thinking see Follman (1994a) for an exhaustive compilation of critical thinking correlations, some eight pages in excess of 700 coefficients, the nomothetic network of critical thinking research relationships. Also see Follman (1994b) for a companion compilation of correlations of the nomothetic network of the related, but much smaller, literature of the construct of critical reading.

Finally, starting on the next page, is a list of critical thinking tests, clienteles, and references. The tests are sorted more or less into tests readily available or tests not readily available. Also, examination of the references herein will indicate additional measures of critical thinking which are not included herein primarily because of the difficulty in obtaining them. 
Critical Thinking Tests

Tests Readily Available

TEST

Academic Profile Test (ETS)

CLIENTELE

G15+

Analysis of Arguments

Assessing Higher Order Thinking Skills

Basic Skills for Critical Thinking

G9-12

Califomia Critical Thinking Skills Test: Form A College

Califomia Critical Thinking Skills Test: Form B College

California Critical Thinking Disposition Inventory

Cognitive and Analytical Skill Test

College

College Outcomes Measures Project

Collegiate Assessment of Academic Proficiency College COMP-Objective Test (ARTP)

Cornell Class Reason. Test Form X

Comell Cond, Reason. Test Form X

Cornell Critical Thinking Test Level X )

Comell Critical Thinking Test Level $Z$

Critical Thinking Skills (History/Soc.St.)

Curry Test of Critical Thinking

Developing Cognitive Abilities Test

Ennis-Weir Argumentation Test

Ennis-Weir Critical Thinking Essay Test

Group Assessment of Logical Thinking

Graduate Record Examination

Judgment: Ded. Log. \& Ass. Recog.

Logical Reasoning

MAPCritical Thinking

Maryland Center for Think. Studies System

New Jersey Test of Reasoning Skills

Preference for Cognitive Complexity Test

PRIDE 1 (reason critically in social work)

Reflective Judgment Interview

Ross Test of Higher Cognitive Processes

Soloff \& Houtz

Test of Problem Solving 1984

Test of Thematic Analysis

Test on Appraising Observations

Valett Inventory of CT Abilities

Watson-Glaser Critical Thinking Appr.

Whimbey Analytical Skills Inventory
G 4-14

G5-11

G4-14

Adults

G 8

College

G7-16+

G 16+

G 7-12

G9+

G3-5, 6-11

G 4-9

G4-16t

College

University

G9+

G4-College

GK-4

G6-12

G7-14

Age 4-5+

G9+
REFERENCE

Facione (1989)

Baker (1981)

Arter \& Salmon (1987)

Baron (1987)

Facione (1992)

Facione (1992)

Facione \& Fac. (1992)

Chovan \& McG. (1985)

Baker (1981)

Pascarella et al. (1994)

Baker (1981)

Kennedy et al.(1987)

Stewart (1979)

Baron (1987)

Baker(1981)

Kneedler (1986)

Landis\& Michael (1981)

Torres \& Cano (1995)

Facione (1990)

Ennis (1986)

Yeany, Yap \& Padilla

Facione (1989)

Norris \& Ennis (1989)

Kennedy et al. (1987)

Moss \& Koziol (1991)

Worsham (1991)

Follman (1987, Summer)

Chovan \& McG. (1985)

Gibbs et al. (1995)

Stewart (1979)

Baron (1987)

Follman (in progress,c)

Facione (1990)

Baker (1981)

Norris (1988, Fall)

Facione (1990)

Baker (1981)

Whimbey (1985) 


\section{Tests Not Readily Available}

TEST

A Test of Critical Thinking Form $G$

A Test of Crit. Think. in the Soc. Sci.

ACTP Collegiate Ass. of Acad. Prof.

Basic Skills Assessment 1977-81

Ball Aptitude Battery

Charles Logan unnamed test

Charley Brown unnamed test

Corrective Reading Mastery Test 1984 (SRA)

Creative Writing on a Social Problem

David Simon unnamed test

Interpretation of Data Test

Inventory of Social Understanding I

Meno

Near Transfer Critical Thinking Test

Pearson Hyram Test of CT

Recognizing Reliable Observations

Smith-Sturgeon Conditional Reas.

Social Issues Analysis Test 1

Social Issues Analysis Test 2

Social Issues Analysis Test 3

Social Issues Analysis Test 4

Test of Cognitive Skills 1981

Test of Enquiry Skills (Australia)

Test. of Study Skills \& Crit. Th. II

Test. of Study Skills \& Crit. Th. V

Test. of Study Skills \& Crit. Th. VI

Test. of Study Skills \& Crit. Th. XIII

Test. of Study Skills \& Crit. Th. XV

Test. of Study Skills \& Crit. Th. XVI

Test. of Study Skills \& Crit. Th. XVII

Uncritical Inference Test
CLIENTELE REFERENCE

G9+

(author)

Baker (1981)

G13+ Facione (1990)

Adults Facione(1990)

Facione (1990)

Baker (1981)

Baker (1981)

Facione (1990)

Baker (1981)

Baker (1981)

G9-12 Stewart (1979)

Baker (1981)

Adults Cambridge (1992)

Edelman \& Hudgins

Stewart (1979)

Stewart (1979)

G 1-3 Ennis et al. (1969)

Baker (1981)

Baker (1981)

Baker (1981)

Baker (1981)

G2-12 Facione (1990)

G 7-10 Kennedy et al. (1987)

Baker (1981)

Baker (1981)

Baker (1981)

Baker(1981)

Baker (1981)

Baker (1981)

Baker (1981)

G 12+ Stewart (1979)

\section{REFERENCES}

Arter, J.A., \& Salmon, J. (1987, December). How to choose the best instruments for measuring school climate and thinking skills. Sketches, Washington, DC: Office of Educational Research and Improvement, U.S. Department of Education.

Baker, P.J.(1981). Learning sociology and assessing critical thinking. Teaching Sociology, $8,325-363$. 
Baron, J.B. (1987). Evaluating thinking skills in the classroom. Teaching thinking skills:

Theory and practice. Edited by J.B. Baron \& R.J. Sternberg. New York: W.H. Freeman and Company.

Burton, W.H., Kimball, R.B., \& Wing, R.L. (1960). Education for effective thinking. New York: Appleton-Century-Crofts, Inc.

Cambridge seeks hidden potential. (1992). Critical Thinking, 1, 10.

Chovan, W., \& McGann, S.M.P.(1985). Problem solving activities and transactions among college students: A process-oriented approach. Teaching Thinking Problem Solving, 7 (January/February), 1-2,4.

Edelman, S., \& Hudgins, B.B. (undated). Near Transfer Critical Thinking Test. St. Louis, MO: Washington University, Department of Education.

Ennis, R.H. (1986). Tests that could be called critical thinking tests. In Thinking in the classroom. Edited by P. Chance. New York: Teachers College Press.

Ennis, R.H., et al. (1969). Conditional logic and children. Ithaca, NY: Cornell University, College of Agriculture, Comell Critical Thinking Readiness Project, Phase IIC.

Facione, P.A. (1989). A quick list of CT assessment tools. CT NEWS, 7 (March/April).

Facione, P.A. (1990). Critical thinking: A statement of expert consensus for purposes of educational assessment and instruction. Research findings and recommendations. $E D$ 315423.

Facione, P.A. (1992). The California Critical Thinking Skills Test and Test Manual. Millbrae, CA, The California Academic Press.

Facione, P.A., \& Facione, N.C. (1992). The California Critical Thinking Disposition Inventory and Test Manual. Millbrae, CA, The California Academic Press.

Follman, J. (1987). Critical thinking instruments: Instruments of plenty or plenty of instruments? Florida Educational Research Council Research Bulletin, 20 (Summer), 71-75.

Follman, J. (1987). Contemporary critical thinking activity update. CT News, 6 (November/December), 1, 4-7.

Follman, J. (1991). Critical reading revisited. CT News (November/December), 10, 1-3.

Follman, J. (1994a). Comucopia of correlations X: Critical thinking. Paper presented at the annual meeting of the Florida Educational Research Association, Tampa, Florida, November 11 .

Follman, J. (1994b). Cornucopia of comelations XIV: Critical reading. Paper presented at the annual meeting of the Florida Educational Research Association, Tampa, Florida, November 11.

Gibbs, L., Gamrill, E., Blakemore, J., Begun, A., Keniston, A., Peden, B., \& Lefcowitz, J. (1995). A measure of critical thinking about practice. Research on Social Work Practice, 5, 193-204.

Glaser, E.M. (1941). An experiment in the development of critical thinking. New York: Columbia University, Teachers College, Bureau of Publications, No, 843.

Kennedy, M., Fisher, M.B., \& Ennis, R.H. (1987). Critical thinking: Literature review and needed research. Paper presented at the annual meeting of the American Educational Research Association, Washington, D.C.

Kneedler, P. (1986). In Thinking in the classroom. Edited by P. Chance. New York: Teachers College Press. 
Landis, R.E., \& Michael, W.B. (1981). The factorial validity of three measures of critical thinking within the context of Guilford's Structure-of-Intellect model for a sample of ninth-grade students. Educational and Psychological Measurement, 41, 1147-1166.

Moss, P.A., \& Koziol, S.M., Jr. (1991). Investigating the validity of a locally developed critical thinking test. Educational Measurement: Issues and Practice, 10, 17-22.

National Center for Research to Improve Postsecondary Teaching and Learning (1989). Assessing growth in thinking in college courses: A caveat. Accent on Improving College Teaching and Learning, Ann Arbor, MI: J.S. Stark, Director.

Ness, J.H. (1967). The effects of a beginning speech course on critical thinking ability. Ph.D. dissertation, Minneapolis, MN: University of Minnesota.

Norris, S.P. (1988), Controlling for background beliefs when developing multiple-choice critical thinking tests. Educational Measurement: Issues and Practice, 7(Fall), 5-11.

Norris, S.P., \& Ennis, R.H. (1989). Evaluating critical thinking. Pacific Grove, CA: Midwest.

Pascarella, E., Edison, M., Whitt, E.J., Nora, A., Hagedorn, L.S., \& Terenzini, P. (1994). Cognitive effects of Greek affiliation during the first year of college. National Center on Postsecondary Teaching, Learning, and Assessment, University Park, PA, ED 381053.

Ranbom, S. (1985). Michigan board approves tests to assess critical thinking skills. Education Week (March 6), 4.

Sternberg, R.J., \& Baron, J.B. (1985). A statewide approach to measuring critical thinking skills. Educational Leadership, 43, 40-43.

Stewart, B.L. (1979). Testing for critical thinking: A review of the resources. Rational Thinking Reports Number 2. Urbana, Illinois: Illinois University.

Torres, R.M., \& Cano, J. (1995). Examining cognition levels of students enrolled in a college of agriculture. Journal of Agricultural Education, 36, 46-54.

Vobejda, B. (1988). Students reported deficient in critical-thinking skills. Washington Post (February 26), A 17.

Whimbey, A. (1985). You don't need a special "reasoning" test to implement and evaluate reasoning training. Educational Leadership, 43 (October), 37-39.

Worsham, T. (1991). Assessing classroom thinking in action. Alternatives to the paper and pencil test. Teaching Thinking and Problem Solving, 9-12.

Yeany, R.H., Yap, K.C., \& Padilla, M.J. (1986). Analyzing hierarchical relationships among modes of cognitive reasoning and integrated science process skills. Journal of Research in Science Teaching, 3, 277-291. 